\title{
Antibacterial peptides from thermophilic bacteria
}

\author{
Karel Mikulík ${ }^{1}$, Magdalena Melčová ${ }^{2}$, Jarmila Zídková ${ }^{3}$ \\ ${ }^{1}$ Institute of Microbiology, Academy of the Czech Republic Vídenská 1083 14220, Prague 4 \\ ${ }^{2,3}$ Department of Biochemistry and Microbiology, Institute of Chemical Technology Prague 6, Czech Republic
}

\begin{abstract}
It is becoming interestingly apparent that innovations of the classical antibiotics are not effective, that induces need for novel drugs. Peptide antibiotics exhibit a group of secondary metabolites with hydrophobic and cyclic structures containing d-amino acidc like compounds with more resistant to proteolytic degradation. Bacterial peptides can possess bactericidal, fungicidal, metal chelating and immunomodulation activities. Several bacteriocins are active as food preservation, resulting in foods with more naturally preserved and rich in nutritional properties. Antimicrobial peptides used against infections are isolated mainly from mesophilic bacterial species. Novel antibacterial peptides from thermophilic species are more stable at higher temperatures and $\mathrm{pH}$, and can be improved by variation of cultivation conditions. These cells can growth either autotrophically or heterotrophically. Under mixotrophic conditions can utilize pyruvate or hydrogen with thiosulfate. The present review provides a general overview on primary structure of selected antibiotic peptides and their potential for industrial purposes as well as environmental and biotechnological applications.
\end{abstract}

Keywords - antibacterial peptides, novel drugs, metabolites, hydrophobic structure, immunomodulation.

\section{INTRODUCTION}

The genus Geobacillus contains, more than 25 species, which were detected in thermophilic areas around the world. Geobacillus thermodenitrificans N680-2 produces a nisin analogue termed geobacillin I (Fig.1 B). This peptide was produced by heterologous expression in Escherichia coli. NMR results showed that geobacillin I incorporates seven thioester cross-lings and demonstrates increased stability compared with nisin. Antimicrobial activity of geobacillin I is similar to nisin A. The genome of G.stearothermophilus NG80-2 contains a gene product with a ring topology distinct from any known lantibiotics. The geobacillin II exhibits antibiotic activity against Bacillus only (Garg et al., 2012). Only bacteriocins type I nisin, mutacin (Fig. 1C) and planeosporin are active against multidrug resistant Gram-positive bacteria (Severina et al., 1998; Fontana et al., 2006). Bacteriocin production is stabile even at $55^{\circ} \mathrm{C}$ and is dependent on the time of incubation, $\mathrm{pH}$ and concentrations of nitrogen.
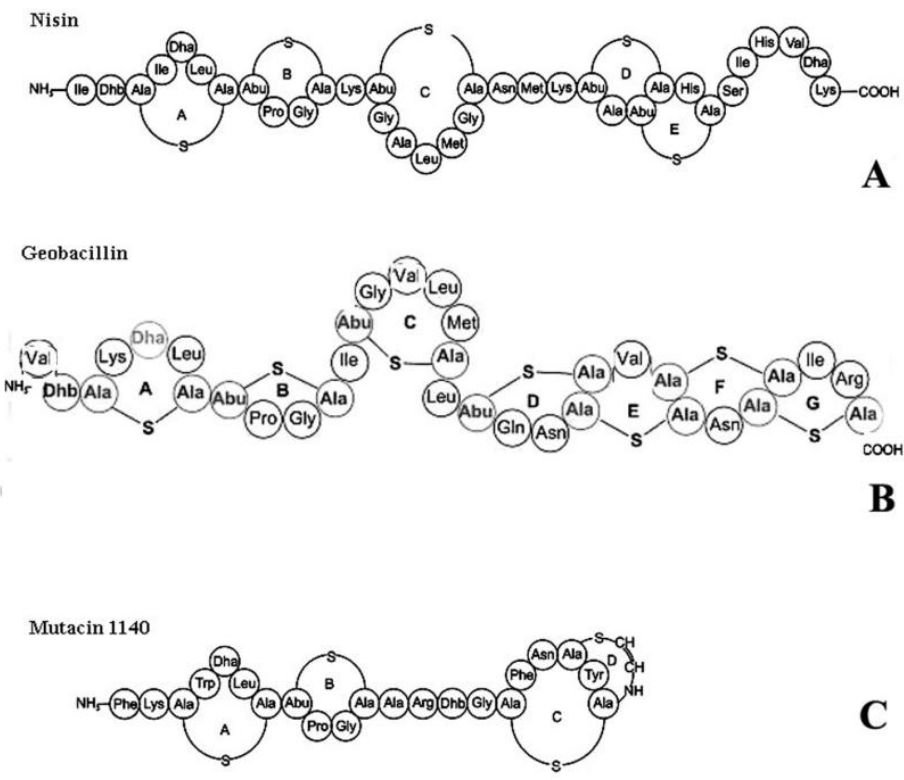

C

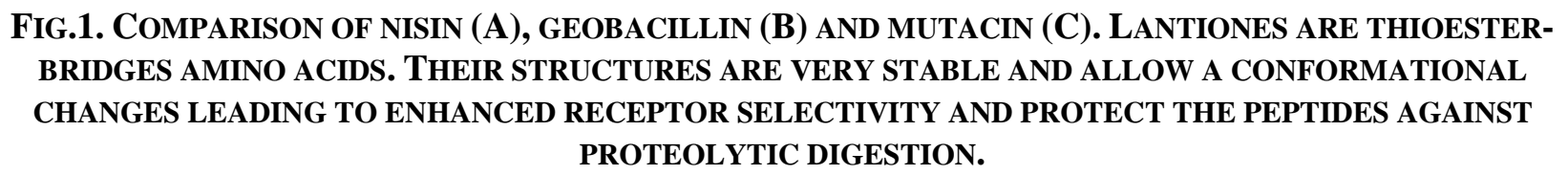

Dhb-dehydrobutiline; Dha-dehydroalanine; Abu- aminobutyric acid. 
From thermal areas near to Yellowstone National Park Geobacillus M7 strain was isolated. The cells of this bacterium are globous and they are covered by a capsular layer with bacilliform structures. The bacteria generate petal shaped colonies when grown on nutrient agar at neutral $\mathrm{pH}$ and temperatures between 55-65 ${ }^{\circ} \mathrm{C}$. 16S RNA of M-7 has a $97 \%$ similarity with G.stereothermophilus. This strain produces volatile compounds (VOCs) with antibacterial activity such as benzaldehyde, acetic acid, butanol-3-methylbutanoic acid, 2- methyl-butanoic acid, propanoic acid, 2- methyl and benzeneacetaldehyde. These compounds inhibit growth of Aspergillus fumigatus, Botrytis cinerea, Verticullium dahliae, and Geotrichum candidum after $48 \mathrm{~h}$, and cells are killed after $72 \mathrm{~h}$ exposure. A mixture of synthetic volatile compounds at the same ratios as those found in the Geobacillus M-7 has the same inhibitory effect on activity of the test organism (Ren et al., 2010). Aeribacillus palidus SAT4 produses antimicrobial peptide at extreme conditions at $\mathrm{pH} 5.0$, glucose concentration $2 \%$, glutamic acis at $1.5 \%$ and under agitation at $100 \mathrm{rpm}$ and $55^{\circ} \mathrm{C}$. Antimicrobial compound was isolated from supernatant fluid with precipitation with ammonium sulphate to 50\% saturation. Sediment was fractionationed through Sephadex G-75 permeation chromatography. Antibacterial activity was detected against S.aureus, M. luteus and Ps.aeruginose.

Thermophilic strain of B.licheniformis synthetised bacillosin 490. The peptide was inactivated by pronase E and proteinaseK. The peptide is good antibacterial agent, stabile to heath treatment and wide pH range (Martirant et. al, 2002).

Several Archae can synthetized a small peptides (archeocins) with potential interest to biotechnology (Charlesworth and Burns, 2015). Sulfolobus islandicus produce peptide sulfolobicin at $\mathrm{pH}$ from 2-4 and temperatures between $65{ }^{\circ} \mathrm{C}$ and $85{ }^{\circ} \mathrm{C}$. Halocins are produced from halophilic rods (Torroblance et. al, 1994). Halocins forms two groups based on size. Microhalocins are about $3.6 \mathrm{kDa}$ and higher halocins of $35 \mathrm{kDa}$. Some halocins are able to inhibit growth of S. solfataricus.

\section{PePtides STRUCTURALly RELATED TO NISIN}

Structurally similar substances to nisin were found in many bacteria. Subtilin is 32amino acids pentacyclic lantibiotic (Fig. 2A) was identified in Lactobacillus lactis (Ross et al., 2002). The cluster for subtilin contains specifies genes for subtilin peptide SpaS, posttranslational lantoin formation SpaBC, and translocation gene Spa T for modified species. Proteases (AprE) WprA and Vpr are involved in processing of subtilin (Corvey et al., 2003). Subtilin self-protection is mediated by ABC-translocator Spa FEG and lipoprotein Spa I (Klein and Entian 1994; Stein et al., 2003b). Biosynthesis of subtilin is regulated by sensor histidine kinase SpaK and regulatory protein SpaR that binds to spa-box of DNA, supporting expression of the genes for subtilin biosynthesis spaS, spa BTC and self protection protein Spa FEG (Stein et al., 2003b; Kleerebezem, 2004). Expressions of SpaRK are regulated by sporulation specific factor SigH, which is repressed during exponential growth by regulator AbrB (Fawcett et al., 2000). These data indicate that production of subilin is under dual control by culture density in quorum sensing mode, where subtilin response to the growth phases is directed by the Abrb/SigH (Stein et al., 2002b).

Ericin S (Fig. 2B) is closely related to the subtilin cluster. Subtilisin differs from ericin in four amino acid residues only, but their antibiotic activity is comparable. Ericin A (Fig. 2C) has different amino acid composition and ring organization with ericin S. Although ericin A is fully matured and is produced in equal quantities as ericin $\mathrm{S}$, single synthetases EriC catalyses the development of two different products: ericin A and S. Requirements for single synthetase (EriBC) indicate flexibility of the lantibiotic biosynthetic route.

Mersacidin (Fig. 2D) is comprised of three melane rings along with dehydroalanine and aminovinylmethylcysteine residues. The peptide is synthesized at the beginning of the stationary phase of growth (Guder et al., 2002). Connection between cellular regulatory systems of $B$. subtilis and the mersacidin regulatory network is not known, but Mrsd the Flavin-containing cysteine decarboxylase (HFCD) catalyses oxidative decarboxylation of the C-terminal cysteine of mescacidin pro-peptide. Introduction of amino acids to mersacidin rings exhibits a loss of activity.

Sublancin 168 (Fig. 2E) contains two disulphide bridges and a $\beta$-methyllananthionine bridge. A hybridization probe based on the peptide sequence was used to clone the pre-sublancin gene, which encoded a 56-residue polypeptide consisting of a 19residue leader segment and a 37-residue mature segment. The mature segment contained one serine, one threonine, and five cysteine residues. The sublancin leader was similar to the known type AII lantibiotics, containing a double-glycine motif that is typically recognized by dual-function transporters. A protein encoded immediately downstream from the sublancin gene possessed features of a dual-function $\mathrm{ABC}$ transporter with a proteolytic domain and an ATP-binding domain. The antimicrobial activity spectrums of sublancin were like other lantibiotics, inhibiting Gram-positive bacteria but not Gramnegative bacteria; and like the lantibiotics, nisin and subtilin, are able to inhibit both bacterial spore outgrowth and vegetative 
growth. Sublancin is an extraordinarily stable lantibiotic, showing no degradation or inactivation after being stored in an aqueous solution at room temperature for two years (Paik et al., 1998).

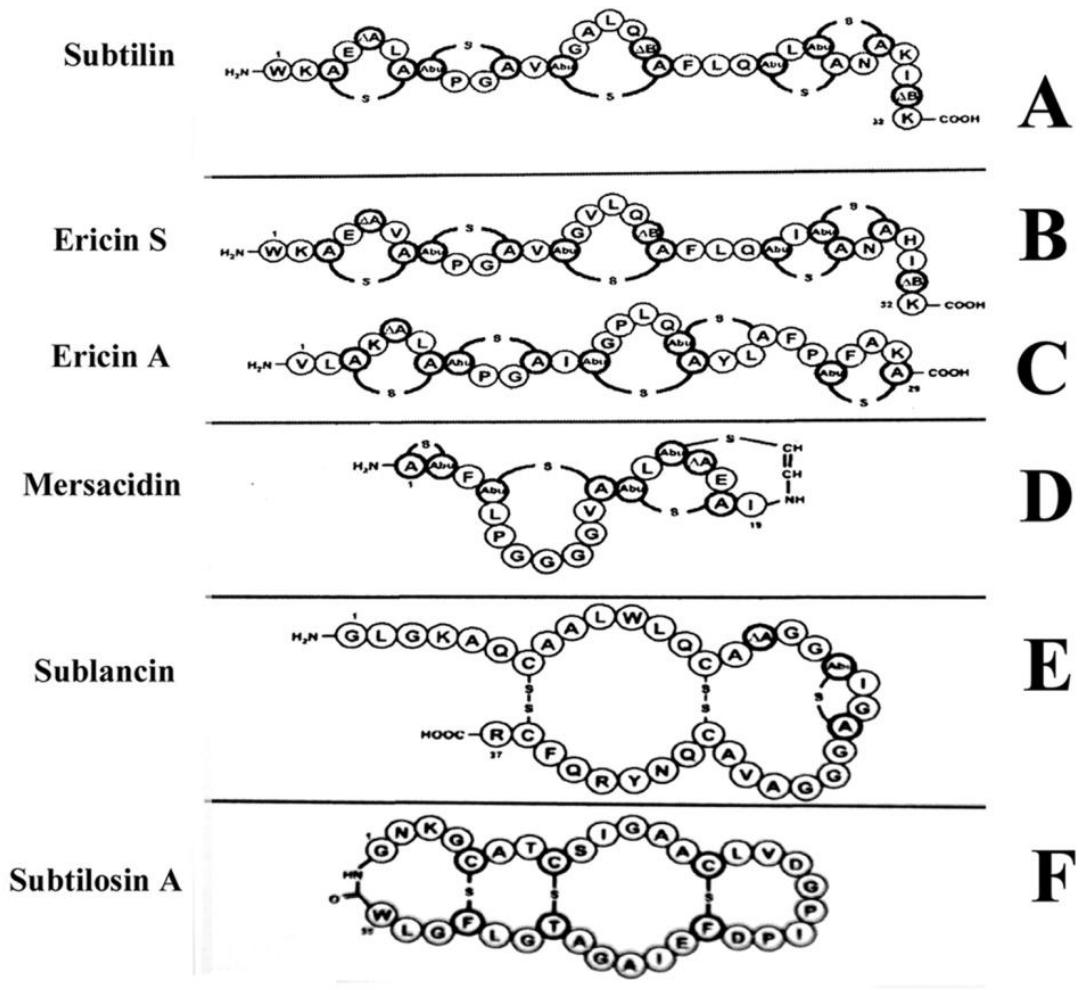

\section{Fig.2. Pentacyclic lantibiotics -Subtilin (A); Ericin S (B); Ericin A (C). UnUSual lantibiotics WITH MACROCYCLIC STRUCTURE AND WITH ONE MERSACIDIN (D); TWO-SUBLANCIN (E) ; AND THREE INTER-RESIDUAL LINKAGES SUBTILOSIN A (F).}

Subtilolisin A (Fig. 2F) has a macrocyclic structure with three inter-residual linkages (Marx et al., 2001) and is produced by B. subtilis (Zheng et al., 1999; Stein et al., 2004). In the processing of subtilolisin AlbF (YwhN) protein and immunity proteins AlbB-D (YwhQPO) are included (Zheng et al., 2000). It has been shown that inter-residual connection is mediated by the thioester bond between cysteine sulphur and alfa amino acid carbons (Kawulka et al., 2004). Subtilolisin is active against Gram-positive bacteria including Listeria (Zheng et al., 1999). The Antilisterial bacteriocin cluster encodes AlbA (YwiA) protein which is probably involved in post-translational modification of pre-subtilosin. Expression of the antilisterial bacteriocin (sbo-alb) is under AbrB control (Zheng et al., 1999) and under stress conditions (Nakano et al., 2000).

From municipal solid waste a strain of Brevibacillus borstelensis RH 102 was isolated a component with good activity against G+ bacteria (M. flavus, S .aureus, B. subtilis and Difzia K44). Antibiotics produced at $60{ }^{\circ} \mathrm{C}$ that are soluble in methanol and water suggests a polar nature of their active components (Venugopalan et al., 2013).

\section{TWO COMPONENT LANTIBIOTICS}

Lacticin 3147 (Fig. 3A) contains two melan and two lan rings D-alanine, and two Dhb residues (Ryan et al., 1996). Lacticin 3147 was identified in a supernatant solution of Lactococcus lactis (DPC3147). This bacteriocin is very active against Listeria monocytogenes and resistant strains of Staphylococcus aureus, vancomycin resistant Enterococci, penicillin resistant Pneumococcus and Streptococcus mutant strains (McAuliffe et al., 1999). Lacticin 3147 is an effective protective agent in the production of cheese. Solid phase peptide synthesis was used in examination of the role of lan and melan residues in lactin 3147. Three ring analogues were synthesized. When thioester of lan or melan is oxidized, the peptide loses its antibacterial activity. Lactococcus lactis also produces lactin 481 containing one melan, andthe two lan rings with one Dhb residue. Each ring can exist as lan or melan, and the peptide remains active. When the ring was opened the peptide lost activity (Rince, 1994).

Haloduracin $\beta$ (Fig. 3B) is a two-component lantibiotic comprising $\alpha$-globular peptide and elongated $\beta$-peptide. This peptide was identified in Bacillus halodurans. Haloduracin $\alpha$ consists of one lan, one cysteine, two melan rings and three Dhbs. 
Haloduracin $\beta$ contains one lan, three melan groups and three Dhbs. Haloduracin is more stable at $\mathrm{pH} 7$ than nisin. Ring $\mathrm{A}$ has a small effect on activity in contrast to rings $\mathrm{C}$ and $\mathrm{D}$ that are important for activity. $\mathrm{N}$-terminal cysteine of peptide is not essential for activity. Haloduracin synthesis is accompanied by sporulation and stationary cultures and spores containing haloduracin peptides were collected. Two products with 2.332 Da and 3.046 Da were identified (McClerren et al., 2006).

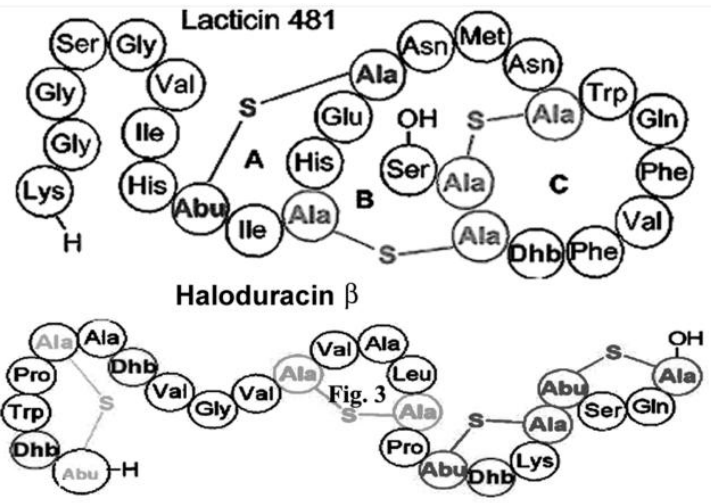

A

B

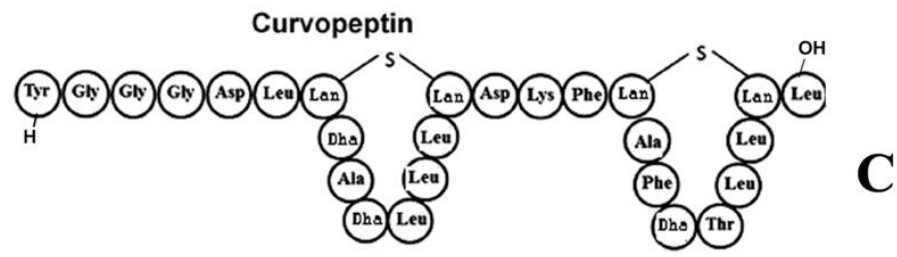

FIG.3. THE TWO-PEPTIDE LANTIBIOTICS DESCRIBED AMONG BACILLI HALODURACIN (FIG. 3B) AND LICHENICIDIN ARE CLOSELY RELATED TO TWO-PEPTIDE LANTIBIOTICS PRODUCED IN OTHER BACTERIA SUCH AS LACTICIN (FIG. 3A) PRODUCED BY L. LACTIS DPC3147. CURVOPEPTIN (FIG. 3C) FROM THERMOMONOSPORA CURVATA IS THE FIRST CLASS III LANTIBIOTIC OF THERMOPHILIC ORIGIN.

Thermomonospora curvata synthetizes Curvopeptins (Fig. 3C), that is labionin-carbocyclic variant of lantione (Krawczyk et al., 2012). Enzymatic studies with a precursor peptide mutant allowed the assignment of all dehydration sites. Curvopeptin biosynthesis of nine intermediates was studied by high-resolution mass spectrometry combined with deuterium-labeling. This approach makes it possible to create a model of three post-translational modification reactions: phosphorylation, elimination, and cyclization. These data support the characterizetion of the modifying enzyme CurKC, and in particular its specificity toward phosphorylation co-substrates. The enzyme accepted NTPs and dNTPs although the purine nucleotides ATP/dATP and GTP/dGTP were the preferred co-substrates. These data give important mechanistic insights into the processing and directionality of the multifunctional class III modifying enzymes (Jungmann et al., 2014).

Bacillus thermoleovorans S-II and B. thermoleovorans NR-9 produce bacteriocins: thermoleovorin-S2 and thermoleovorin$\mathrm{N} 9$, respectively. The bacteriocins are stable at $\mathrm{pH}$ from 3 to 10 and at temperatures $70-80^{\circ} \mathrm{C}$. Thermoleovorins are produced during log-phase growth and are inhibitory to actively growing cells, they are effective against Salmonella typhimurium, Branhamella catarrhalis, Streptococcus faecalis, and Thermus aquaticus. The bacteriocins are digested by protease type XI and pepsin. Thermoleovorin-S2 was more thermostable than thermoleovorin-N9 at 70 and $80{ }^{\circ} \mathrm{C}$. Thermoleovorins-S2 and N9 apparently act by binding to susceptible organisms, resulting in lysis of the cell. Thermoleovorins-S2 has an estimated M(r) of 42,000, while thermoleovorin-N9 has M(r) of 36,000. (Novotny and Perry,1992). The ability of thermoleovorins to inhibit Salmonella typhimunum, Branhamella catarrhalis, and Streptococcus faecalis was an unexpected finding. The antimicrobial effect on Salmonella typhimurium permits further investigation and may provide a use for these bacteriocins either in the food industry or as a feed additive for poultry. From composts thermophilic bacteria sensitive to penicillin $G$ were isolated. Facultative autotrophic strains isolated from hot composts were Gram-variable rods with terminal endospores. Optimum temperature for growth was between $65-70{ }^{\circ} \mathrm{C}$. These cells can growt either autotrophically or heterotrophically with hydrogen, or can oxidize thiosulfate. Under mixotrophic conditions they can utilize pyruvate or hydrogen with thiosulfate. DNA content and DNA: DNA homology of these strains had more than $75 \%$ with a reference strain of Bacillus schlegelii. Strains with inhibitory effects against pathogenic bacteria were isolated from cow manure compost. These bacteriocin-like components were thermal unstable (Abdel-Mohsein et al., 2003). Supernatant solutions of Bacillus licheniformis H1 inhibit growth of various Gram negative bacteria, e.g. Listeria monocytogenes ATCC 19111, but with the exception of Pseudomonas fluorescents ATCC11251, bacteriocin(s) are inactivated by proteolytic enzymes (chymotrypsin, 
trypsin and papain) and are stable under $\mathrm{pH}$ from 3 to 9 and temperatures up to $75{ }^{\circ} \mathrm{C}$. Using SDS-polyacrylamide gel electrophoresis of partially purified supernatant an active protein with $\mathrm{M}_{\mathrm{r}}$ approximately $3.5 \mathrm{kDa}$ was identified. Streptococcus thermophilus producing bacteriocin that lost antibacterial activity after incubation $1 \mathrm{~h}$ at $60{ }^{\circ} \mathrm{C}$ was isolated from raw milk. When co-cultured with Lactobacillus delbruecki susp. Lactis, the production of bacteriocin was enhanced. The isolated bacteriocin termophilin T (Aktypis et al., 1998) from S.thermophilus ACA-DC 0040 inhibits both lactic acid bacteria and clostridia. The inhibition of clostridia was also described for acidocin B (tenBring et al., 1994) and pedocins (Daeschel, 1989; Ray et al., 1989). Thermophilin T regulates population dynamics in the yogurt production and hard cheeses. Since proteolytic enzymes and $\alpha$-amylase inactivate thermophilin $\mathrm{T}$, this indicates that bacteriocin is glycoprotein.

Paracin 1.7 is peptide produced by Lactobacillus paracasei HD1-7 from sauerkraut juice. The molecular mass of Parecin 1.7 was about $10 \mathrm{kDa}$. The N-terminal structure was similar to that of an ABC-oligopeptide transport system. Paracin 1.7 was sensitive to protease $\mathrm{K}$, had antimicrobial activities at a broad $\mathrm{pH}$ range (3.0-8.0), and was heat resistant (121 ${ }^{\circ} \mathrm{C}$ for $20 \mathrm{~min}$ ). Paracin 1.7 from Lactobacillus paracasei HD1-7 is a novel bacteriocin that has potential applications in food preservation. Paracin 1.7 shows a broad spectrum of activities against various strains in the genera of Proteus, Bacillus, Enterobacter, Staphylococcus, Escherichia, Lactobacillus, Microccus, Pseudomonas, Salmonella and Saccharomyces, some of which belong to food borne pathogenic bacteria (Ge et al., 2016)

Amylocyclin is a circular bacteriocin produced by Bacillus amyloliquefaciens FZB 42 (Scholz et al., 2014) which is released into cultivation medium. Amylocyclin with molecular mass of 6. $381 \mathrm{Da}$ is synthetized on ribosomes. Self-protections against drug produced is directed by small cationic peptides AcnC, AcnO, AcnE and AcnF. The drug inhibits Gram-positive cells only. Amylocyclicin is released into the culture medium by wild-type strain B. amyloliquefaciens FZB42 and sfp mutants derived from there. It can be obtained from ammonium sulfate precipitation of the supernatants, followed by extraction of the pellet with methanol. In addition, the bacteriocin is attached in an appreciable amount to the outer surface of the bacterial cells, from where it can be extracted with a $50 \%$ aqueous acetonitrile- $0.1 \%$ trifluoroacetic acid. Such surface extracts are the source of choice for further purification and characterization of the bacteriocin.

\section{NON-RIBOSOMAL SYNTHESIS OF PEPTIDE ANTIBIOTICS}

Large multienzymes non-ribosomal peptide synthetases (NRPSs) contain domains that catalyse ordered selections and polymeration of amino acid residues (Sieber and Marahiel 2003; Finking and Marahiel, 2004). Elongation steps in peptide biosynthesis need three core domains: i) The 350 amino acid residues of adenylation domain, are required for recognition of cognate amino acid, which resembles the acylation of tRNA synthetases during ribosomal peptide synthesis. ii). The peptidyl carrier domain containing 4'phosphopantheine group accepting adenylated amino acid under thioesterification and release of AMP. The 4'phosphopantheine cofactor serves as a transporter of intermediates between various catalytic domains. Peptidyl carrier proteins are posttranslationally modified from inactive apoforms to holoforms by 4'phosphopantheine-transferases (Lambalot et al., 1996). iii) Condensation domains (450 aa), which are located between pair of adenylation and peptidyl carrier domains catalysing formation of peptide bonds (Herbst et al., 2013). Biosynthesis is terminated by cyclization of the peptide (Kohli and Walsh, 2003) and such reactions are catalysed by thioesters-part of C-terminus. Lipopeptide antibiotics with $\beta$-hydroxyl or $\beta$ amino fatty acids are synthetized in Bacillus subtilis. The branching and length of the chains of amino and fatty acids participate in microheterogeneity (Kowall et al., 1998). The most-well known lipopeptide surfactin (20nM) causes a decrease in tension of water from 72 to $27 \mathrm{mMm},{ }^{-1}$ and it is an efficient detergent on cell membranes (Carrillo et al., 2003). PCR screening for the presence of nonribosomal synthetase and polyketide synthetase show a role of antibiotic lipopeptides as a potential resource of novel therapeutic drugs (Palomo et al., 2013).

Rhizovital is a lipopeptide antibiotic produced by B. amyloliquefaciens FZB42 (Sylla, et al., 2013) and the product requires sfp-dependent 4'phosphopanteinyl transferase to transmit 4'phosphopanteinyle from coenzyme A onto peptidyl carrier protein. RhizoVital 42 fl. suppresses Botrytis cinerea infections.

Surfactin (Fig. 4A) catalyse the three peptide synthetases Srf A-C. The thioesterase/acyltransferase enzyme SrtD initiates the process (Steller et al., 2004). The excretion of surfactin by passive diffusion across the cytoplasmic membrane is anticipated. Resistance to surfactin is acquired by the YerP multidrug efflux pump (Tsuge et al., 2001a). Production of surfactin is regulated by the 4'phosphopantheine transferase Sfp that transmit inactive apoform of surfactin and fengycin synthetase to active holoform (Lambalot et al., 1996; Mootz et al., 2001). The transfer of native stp allel into Bacillus subtilis induces the production of surfactin (Nakano et al., 1992) and fengycin (Tosato et al., 1997). Biosurfactant from certain strains of Bacillus and Pseudomonas are mixtures of different lipopeptides or isoforms (Naruse et al., 1990; Abalos et al., 2001; Vater et al., 
2002; Mukherjee and Das 2005). Surface tension or antimicrobial properties of lipopeptides are dependent on its molecular structure. Branching and length of the chains of amino and fatty acids participate in microheterogeneity (Kowall et al., 1998). The antimicrobial part of the biosurfactant is formed by lipopeptides. The biosurfactant and surfactin showed overlapping patterns in IR spektra, characteristic of lipopeptides (Lin et al., 1994). The iturin family includes cyclic lipopeptides mycosubtilin (Fig. 4B), iturins (Fig.4C), and bacillomycins (Fig. 4D). These compounds are antifungal and haemolytic, but their antibacterial activity is low (Thimon et al., 1995). The synthesis of these peptides catalyses similar nonribosomal peptide synthetases: mycosubtilin (Duitman et al., 1999), iturin (Tsuge et al., 2001b) and bacillomycin synthetases (Moyne et al., 2004). Fengycin (plipastatin) (Fig. 4E) inhibits growth of filamentous fungi (Vanittanakom et al., 1986) and contains $\beta$ hydroxy fatty acids ligated to the $\mathrm{N}$-terminus of a decapeptide including four $\mathrm{D}$-amino acids. $\mathrm{C}$ terminal residue of the peptide part is connected to the tyrosine residue, forming branching points of acylpeptide and cyclic lactone. Fengycin is synthesized by a complex of fengycin synthetases (Fen1-Fen5) (Steller et al.,1999) that are regulated with fen operon, catalysing different properties as cyclization, branching and unusual constituents. For fenglycin biosynthesis, the UP element between -55 and -39 position in feng DNA of $B$. subtilis is important. Other factors than UP may regulated the transcription of fengycin. More detailed analysis must be conducted as to how these factors operate in biosynthesis of fengycin.
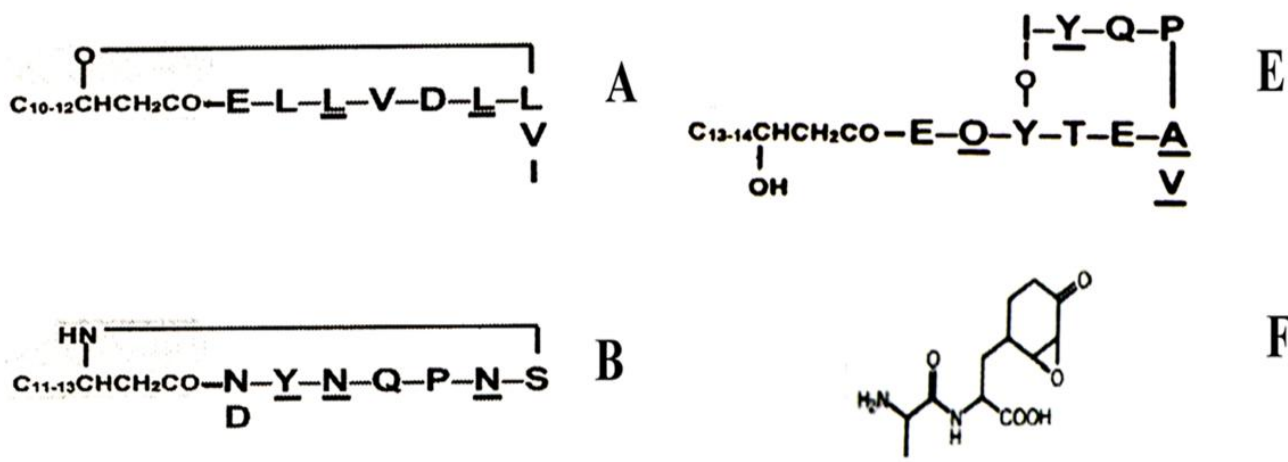

\section{F}
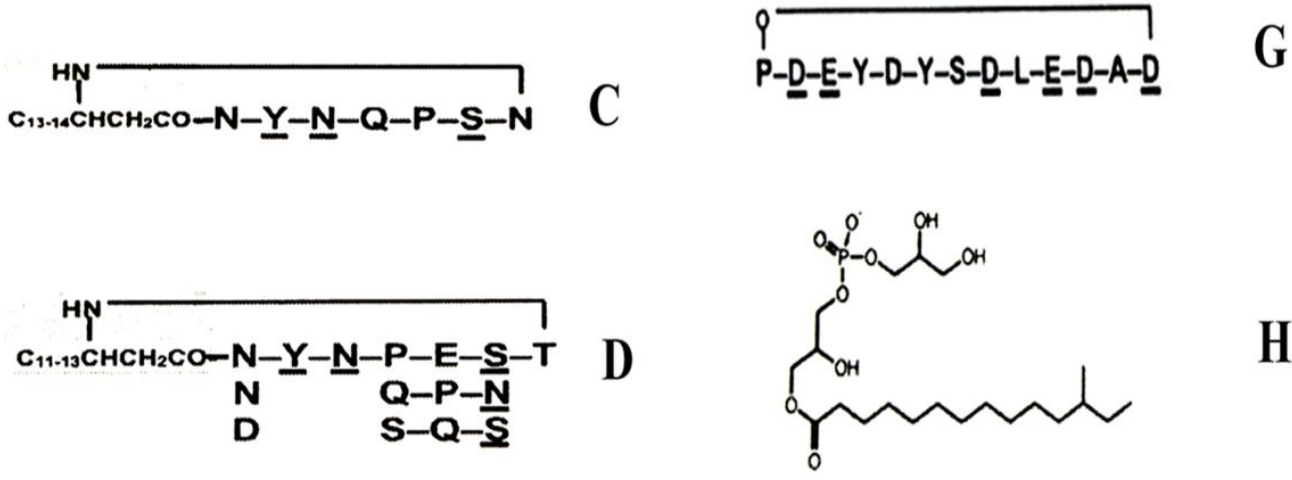

\section{$\mathrm{H}$}

\section{Fig.4. NON-RIBOSOMALLY GENERATED PEPTIDE ANTIBIOTICS. SURFACTIN (FIG.4A); ITURIN (FIG. 4B); MYCOSUBTILIN (FIG.4C); BACILOMYCIN (FIG.4D), FENGYCIN (FIG.4E); BACILYSIN (FIG. 4F); MYCOBACILLIN (FIG.4G) AND RHIZOCTICIN (FIG. 4H).}

Taromycin A is a lipopeptide antibiotic produced by marine actinomycete Saccharomonospora CNQ-490. Taromycin gene tar is similar to the antibiotic daptomycin from Streptomyces raseosporus, but there are differences in the three amino acids and a lipid side chain (Yamanaka et al., 2014). Streptomyces roseosporus produced an acidic lipodepsipeptide antibiotic Daptomycin by a nonribosomal peptide synthetase (NRPS) mechanism (Walsh and Fischbach, 2010). Daptomycin is composed of a 13-member peptide, cyclized to form a 10-member ring and a 3-member exocyclic tail, to which is attached a decanoic acid side chain to the $\mathrm{N}$ terminus of $1-\operatorname{Trp}_{1}$. In the biosynthesis of daptomycin by $S$. roseosporus three nonribosomal peptide synthetases: DptA, DptBC, and DptD are involved.

Fusaricidins are a group of lipopeptide antibiotics produced by Paenibacillus polymyxa (formerly Bacillus polymyxa) and consist of a guanidinylated $\beta$-hydroxy fatty acid linked to a cyclic hexapeptide containing four amino acid residues in the $\mathrm{d}$ configuration (Kajimura and Kaneda, 1996, Kajimura and Kaneda, 1997). In most peptides epimerization of 1-amino acids requires a specialized domnain. An 1-amino acid is activated, and the epimerization (E) domain then catalyzes 1-to-d 
racemization of the thioester-bound amino acid. In the lipopeptide arthrofactin, there are no E domains detected in any of the 3 arthrofactin synthetases, although 7 of the 11 amino acids are in the d-configuration. Additional analyses demonstrated that A domains in modules corresponding to d-amino acids were specific for activation of l-isomers, and epimerase activity was supported by a new type of $\mathrm{C}$ domain with dual epimerization and condensation functions. A third strategy for incorporation of d-amino acids involves the direct activation of d-isomers by the A domains.

Bacilysin (Fig. 4F) the epoxy-modified amino acid anti-capsin (1-alanine [2.3-epoxycyclohexane-4] 1-alanine), depend on the ywfBCDEFGH cluster (Inaoka et. al., 2003) Nonribosomal synthesis of dipeptide is synthesized by Bacillus amyloliquefaciens FZB42 and is independent of Sfp. The genes basDE(ywfEF) encode the function of amino acid ligation as well as bacilysin self-protection (Steinborn et al., 2005). Bacilysin is negatively regulated by GTP via the transcription regulation $A b r B$ and $\operatorname{Cod} Y$. Positive regulation is directed by guanosine-5-diphosphate-3-diphosphate (Inaoka et al., 2003) and a quorum sensing mechanism utilizing peptide PhrC (Yazgan et al., 2003). Bacilysin- has anticyanobacterial activity and thus could be used to moderate the detrimental algal effects (Wu et al., 2014). Bacilysin caused apparent changes in the algal cell wall and cell organelle membranes, and this resulted in cell lysis. Meanwhile, there was downregulated expression of glmS, psbAl, mcyB, and ftsZ - genes involved in peptidoglycan synthesis, photosynthesis, microcystin synthesis, and cell division, respectively.

Mycobacillin (Fig. 4G) is produced by Bacillus subtilis $\mathrm{B}_{3}$. The molecule is formed with cyclic peptide composed of 13 residues of 7 different amino acids (Majumdar and Bose, 1960; 1996), and it is an exclusively antifungal antibiotic. Enzyme complex mycobacillin synthetase was created by the hydroxyapatite column chromatography and sucrose-density-gradient centrifugation; each of the fractions contained migrates as a single component in SDS/polyacrylamide-gel electrophoresis and gel electrofocusing. The Mr of the enzyme fractions A, B and C by gel filtration is 260000,190000 and 105000 and this, by SDS/polyacrylamide-gel electrophoresis, is 252000,198000 and 108 000, respectively. None of the enzyme fractions appears to possess a subunit structure.

Kocurin: Despite the broad distribution of Micrococcaceae in sponges, very little is known about the occurrence of the natural products biosynthetic pathways and the production of bioactive compounds, especially by species of the spongeassociated genera Kocuria and Micrococcus. The production conditions of kocurin by the Kocuria strain F-276,345 were analyzed with a time course study monitoring the growth and kocurin production over 4 days. Kocurin is closely related to two known thiazolyl peptide antibiotics with a similar mode of action, produced by a soil strain of Streptomyces and Planobispora rosea. The strains were PCR screened for the presence of secondary metabolite genes encoding nonribosomal synthetase and polyketide synthases (Palomo et al., 2013), a new member of the thiazolyl peptide family of antibiotics, as a resource for novel drugs.

Rhizocticin (Fig. 4H): Rhizocticins are dipeptide or tripeptide antibiotics and commonly possess 1-arginyl-1-2-amino-5phosphono-3-cis-pentenoic acid. Rhizocticins are produced by the Gram-positive bacterium B. subtilis ATCC6633. Rhizocticin A is 1-arginyl-1-2-amino-5-phosphono-3-cis-pentenoic acid (Arg-APPA); rhizocticin B is-valyl 1-arginyl-1-2amino-5-phosphono-3-cis-pentenoic acid (Val-Arg-APPA); and rhizocticin C and D are the same as rhizocticin B but Val is substituted with 1-isoleucine (Ile) and 1-leucine (Leu), respectively. Rhizocticins enter the target fungal cell through the oligopeptide transport system (Kugler et al., 1990) and then are cleaved by host peptidases to release(Z)-1 -2-amino-5phosphono-3-panteonic acid (APPA), which inhibits threonine synthase, catalyzing the pyridoxal 5'-phosphate (PLP)dependent conversion of phosphohomoserine to 1-threonine (Laber et al., 1994). APPA interferes with the biosynthesis of threonine and related metabolic pathways, initially affecting protein synthesis and leading to growth inhibition. The antifungal effect of rhizocticin A was neutralized by the presence of oligopeptides and amino acids. Phosphinothricin (PT) is the only known phosphinic acid natural product, a non-proteinogenic amino acid found in a number of peptide antibiotics. In Streptomyces viridochromogenes were discovered the compound as a component of a tripeptide antibiotic (PT-Ala-Ala) produced by (phosphinothricin-tripeptide, PTT) or Streptomyces hygroscopicus (bialaphos PT), later it was found as a component of phosalacine, a PT-Ala-Leu tripeptide produced by Kitasatospora phosalacina and trialaphos (PT-Ala-AlaAla), which is a tetrapeptide produced by Streptomyces hygroscopicus KSB-1285 (Higgins et al., 2005; Omura et al., 1984). PT is a structural analog of glutamate and a potent inhibitor of glutamin synthetase. As a free amino acid, PT has relatively poor antibiotic activity, probably due to ineffective transport. Many organisms utilize the peptide versions that are hydrolyzed by cytoplasmic peptidases, releasing the active component. Because glutamine synthetase plays an essential role in $\mathrm{pH}$ homeostasis in plants, PT is an outstanding herbicide and both the tripeptide and synthetic versions of the monomer are widely used in agriculture (Thompson and Seto 1995). 
Thermotolerant actinobacteria, e.g. Streptomyces tauricus, S.lanatus, S.coeruleorubidis, were isolated from the desert of Kuwait during the hot season. These cells were found to inhibit the rhizosphere of many plants and exhibit antimicrobial activity, leading to the protection of plants against phytopathogens (Xue et al., 2013). Thermotolerant streptomycetes isolated from the Himalayan Mountains (Streptomyces phaeoviridis, S.griseoloalbus, S. viridogens) inhibit methicillin resistant and vancomycin resistant strains of Staphylococcus aureus. Strains of Streptomyces viridogens and S. rimosus inhibit growth of pathogenic fungi (Fusarium solani, Rhizoctoconia solani, Colletotricum falcatum and Halminthosporium oryzae) (Radhakrishnan et al., 2007), furthermore, many actinobacteria secreted chelating molecules, retaining a solube form of iron in the rhizosphere of plants grown in iron deficient soil.

The zeamines are peptide antibiotics produced by Serratia plymuthica RVH1 (Masschelein et al., 2015). They exhibit activity affecting the integrity of cell membranes of a broad range of bacteria, including multidrug-resistant pathogens. The zeamines irritate rapid release of carboxyfluorescein from unilamellar vesicles with various phospholipid compositions, allowing them to interact directly with the lipid bilayer. The zeamine also facilitated the uptake of small molecules, such as 1-N-phenylnaphtylamine, making it possible to permeabilize the Gram-negative outer membrane. Zeamine at concentrations required for growth inhibition, causes lysis of membrane as indicated by microscopy. It is probable that the bactericidal activity of the zeamines derived from permeabilization membranes caused electrostatict interactions with the negatively charged part of the membrane components.

Pyrrolamides (e.g. congocidine, distamycin, kikumycins, pyrronamycins, noformycin), constitute a family of natural products produced by Streptomyces or related actinobacteria. They exhibit a variety of therapeutic applications, against viral, bacterial, tumor and parasitic activities (Juguet et al., 2009). Heat-stable antifungal factor (HSAF) is a secondary metabolite produced by the bacterium Lysobacter enzymogenes strain C3. The chemical structure of HSAF suggests that the biosynthesis of this molecule could involve both polyketide and nonribosomal peptide mechanisms, as seen in bleomycins and other natural products. HSAF appears to target a group of sphingolipids that are required for polarized growth of filamentous fungi and appears to be absent from mammals and plants (Yu et al., 2007).

Congocidine (netropsin) consists of peptides that bind to the minor groove of DNA and is a pyrrole-amide antibiotic produced by Streptomyces ambofaciens. Congocidine does not bind single stranded DNA or double stranded RNA; it protects such regions from DNase I and other endonucleases, and also inhibits topoisomerases. This peptide disrupts the cell cycle, prolonging $\mathrm{G}$ and arresting in G. Congocidine is assembled by a nonribosomal peptide synthetase with unusual features (Juguet et al., 2009). Its single adenylation domain acts applicable, and one of its condensation domains preferably uses CoA- as a substrate.A free standing module and the proposed enzyme mechanism may be used to the synthesis of many oligo-pyrrole molecules, and especially distamycin, which comprises three 4-aminopyrrole-2-carbonyl groups.

\section{CONCLUSION}

The post-genomic era will provide much new information on target sites and interactions of protein-protein and protein nucleic acids interactions. One of ultimate goals is to adopt order structures of molecules that can past through cell membranes and interact with specific targets. Peptide antibiotics from thermophiles are suitable for the handling of the structure and are more resistant to proteolytic degradation. Peptides can be safer and more selective than small molecular drugs. There is no need for chemical purification and subsequent separation of isomers. There are several hundred of polypeptides that are in various steps of clinical development. There is need for new antimicrobial peptides with hydrophobicity and $\alpha$-helicity for their activity against mycobacteria in the fight against drug resistant tuberculosis. Natural peptides can be used as food preservatives, chemotherapeutics, and efficient detergents.

\section{REFERENCES}

[1] Abdel-Mohsein, H.S., Sasaki T., Tada, C., Nakai, Y (2003) Characterization and partial purification of a bacteriocin-like substance produced by thermophilic Bacillus licheniformis H1 isolated from cow manure compost. J Dairy Sci. 86:3068-3074.

[2] Abalos, A., Pinazo, A., Infante, M.R., Casals, M., Garcia, F. Manresa, A (2001) Physicochemical and antimicrobial properties of new rhamnolipids produced by Pseudomonas aeruginosa AT10 from soybean oil refinery wastes. Langmuir 17: 1367-1371.

[3] Abed, R.M., Dobretsov, S., Al-Fori, M., Gunasekera, S.P., Sudesh, K., Paul, V.J (2013) Quorum-sensing inhibitory compounds from extremophilic microorganisms isolated from a hypersaline cyanobacterial mat. J IndMicrobiol Biotechnol 40:759-772.

[4] Aktypis, A., Kalantyopoulos, G., Huis, H. J., tenBrink, B (1998) Purification and characterization of thermophilin T, a novel bacteriocin produced by Streptococcus thermophilus ACA-DC 0040. J Appl Microbiol 84:568-576.

[5] Breukink, E, deKruijff B (2006) Lipid II as a target for antibiotics. Nat Rev Drug Discov 5: 321-332. 
[6] Carrillo, C., Teruel, J.A., Aranda, F.J., Ortiz, A (2003) Molecular mechanism of membrane permeabilization by the peptide antibiotic surfactin. Biochim Biophys Acta 1611: 91-97.

[7] Corvey, C., Stein, T., Düsterhus, S., Karas, M., Entian, K.-D (2003) Activation of subtilin precursors by Bacillus subtilis extracellular serine proteases subtilisin (AprE), WprA, and Vpr. Biochem Biophys Res Commun 304: 48-54.

[8] Daeschel, M.A. (1989) antimicrobial substances from lactic acid bacteria. Food Technology 43: 164-167.

[9] Duitman, E.H., Hamoen, L.W., Rembold, M., Venema, G., Seitz, H., Saenger, W (1999) The mycosubtilin synthetase of Bacillus subtilis ATCC 6633: a multifunctional hybrid between a peptide synthetase, an amino transferase, and a fatty acid synthase. Proc Natl Acad Sci USA 96: 13294-13299.

[10] Fawcett, P., Eichenberger, P., Losick, R., Youngman, P (2000) The transcriptional profile of early to middle sporulation in Bacillus subtilis. Proc Natl Acad Sci USA 97: 8063-8068.

[11] Finking, R, Marahiel, M.A (2004) Biosynthesis of nonribosomal peptides. Annu Rev Microbiol 58: $453-488$.

[12] Fontana, G., Savona G., Rodríguez, B (2006) Clerodane diterpenoids from Salvia splendens. J Nat Prod 69:1734-1738.

[13] Garg N., Tang W., Goto Y., Nair S.K., van der Donk W.A (2012) Lantibiotics from Geobacillus thermodenitrificans. Proc Natl Acad Sci USA 109: 5241-5246.

[14] Ge J, Sun Y, Xin X, Wang Y, Ping W (2016) Purification and Partial Characterization of a Novel Bacteriocin Synthesized by Lactobacillus paracasei HD1-7 Isolated from Chinese Sauerkraut Juice. Sci Rep 14:19366.

[15] Guder, A., Schmitter, T., Wiedemann, I., Sahl, H.G., Bierbaum, G (2002) Role of the single regulator MrsR1 and the two-component system MrsR2/K2 in the regulation of mersacidin production and immunity. Appl Environ Microbiol 68: 106-113.

[16] Hamoen, L.W., Venema, G., Kuipers,O.P (2003) Controlling competence in Bacillus subtilis: shared use of regulators. Microbiology 149: 9-17.

[17] Hasper, H.E., DeKruijff, B., Breukink, E (2004) Assembly and stability of Nisin-Lipid II pores. Biochemistry 43: 11567-11575.

[18] Herbst,D.A., Boll, B., Zocher, G., Stehle,T., Heide, L (2013) Structural Basis of the Interaction of MbtH-like Proteins, Putative Regulators of Nonribosomal Peptide Biosynthesis, with Adenylating Enzymes J Biol Chem 288: 1991-2003.

[19] Higgins, L.J., Yan, F., Liu, P., Liu, H.W., Drennan, C.L (2005) Structural insight into antibiotic fosfomycin biosynthesis by a mononuclear iron enzyme.Structures illuminating the mechanism of dehydrogenative epoxide formation. Nature 437:838-844.

[20] Inaoka, T., Takahashi, K., Ohnishi-Kameyama, M., Yoshida, M., Ochi, K (2003) Guanine nucleotides guanosine 5'-diphosphate 3'diphosphate and GTP co-operatively regulate the production of an antibiotic bacilysin in Bacillus subtilis. J Biol Chem 278: 21692176.

[21] Jungmann, N,A., Krawczyk, B., Tietzmann ,M., Ensle, P., Süssmuth, R.D (2014). Dissecting reactions of nonlinear precursor peptide processing of the class III lanthipeptide curvopeptin.J Am Chem Soc 136:15222-15228.

[22] Juguet, M, Lautru,S., Francou F.X., Nezbedová, S., Leblond, P., Gondry, M., Pernodet, J.L (2009) An iterative nonribosomal peptide synthetase assembles the pyrrole-amide antibiotic congocidine in Streptomyces ambofaciens. Chem Biol 16:421-431.

[23] Kajimura $Y^{1}$, Kaneda M (1996) Fusaricidin A, a new depsipeptide antibiotic produced by Bacillus polymyxa KT-8. Taxonomy, fermentation, isolation, structure elucidation and biological activity. J Antibiot 49:129-135.

[24] Kajimura, Y., Kaneda, M (1997)Fusaricidins B, C and D, new depsipeptide antibiotics produced by Bacillus polymyxa KT-8: isolation, structure elucidation and biological activity

[25] J Antibiot 50:220-228.

[26] Kawulka, K.E., Sprules, T., Diaper, C.M., Whittal, R.M., McKay, R.T., Mercier, P (2004) Structure of subtilosin A, a cyclic antimicrobial peptide from Bacillus subtilis with unusual sulfur to alpha-carbon cross-links: formation and reduction of alpha-thioalpha-amino acid derivatives. Biochemistry 43: 3385-3395.

[27] Khalil, A., Sivakumar, N., Qarawi, S (2015) Genome Sequence of Anoxybacillus flavithermus Strain AK1, a Thermophile Isolated from a Hot Spring in Saudi Arabia. Genome Announc Jun 4: 3.

[28] Kleerebezem, M. (2004) Quorum sensing controls of lantibiotic production; nisin and subtilis autoregulate their own biosynthesis. Peptides 25: 1405-1414.

[29] Klein, C., Entian, K-D (1994) Genes involved in self-protection against the lantibiotic subtilin produced by Bacillus subtilis ATCC 6633. Appl Environ Microbiol 60: 2793-2801.

[30] Kohli, R.M., Walsh, C.T (2003) Enzymology and acyl chain macrocyclization in natural product biosynthesis. Chem Commun (Camb) 7: 297-307.

[31] Koponen, O., Takala, T.M., Saarela, U., Qiao, M., Saris, P.E (2004) Distribution of the NisI immunity protein and enhancement of nisin activity by the lipid-free NisI. FEMS Microbiol Lett 231: 85-90.

[32] Kowall, M., Vater, J., Kluge, B., Stein, T., Franke, P., Ziessow, D (1998) Separation and characterization of surfactin isoforms produced by Bacillus subtilis OKB 105. J Colloid Interface Sci 204: 1-8.

[33] Krawczyk, B., Völler, G.H., Völler, J., Ensle, P., Süssmuth, R.D (2012) Curvopeptin: a new lanthionine-containing class III lantibiotic and its co-substrate promiscuous synthetase. Chembiochem 13: 2065-2071.

[34] Kugler, M., Loeffler, W., Rapp, C., Kern, A., Jung, G (1990) Rhizocticin A, an antifungal phosphono-oligopeptide of Bacillus subtilis ATCC6633: biological properties. Arch. Microbiol 153:276-280

[35] Kunst, F., Ogasawara, N., Moszer, I., Albertini, A.M., Alloni, G., Azevedo, V (1997) The complete genome sequence of the grampositive bacterium Bacillus subtilis. Nature 390: 249-256. 
[36] Laber, B., Lindell, S.D., Pohlenz, H.D (1994) Inactivation of Escherichia coli threonine synthase by dl-Z-2-amino-5-phosphono-3pentenoic acid. Arch. Microbiol 161: 400-403.

[37] Lambalot, R.H., Gehring, A.M., Flugel, R.S., Zuber, P., LaCelle, M., Marahiel, M.A (1996)

[38] A new enzyme superfamily-the phosphopantetheinyl transferases. Chem Biol 3: 923-936.

[39] Lin, S.C., Minton, M.A., Sharma, M.M. Georgiou, G. (1994) Structural and immunological characterization of a biosurfactant produced by Bacillus licheniformis JF-2. Appl Environ Microbiol 60: 31-38.

[40] Majumar, S.K., Bose, S.K. (1996) Mycobacillin, a new antifungal antibiotic produced by B.subtilis. Nature 181: 134-135.

[41] Majumar, S.K., Bose, S.K. (1960) Amino acid sequence in mycobacillin. Biochem J 74: 596-599.

[42] Masschelein J., Clauwers, C., Stalmans, K., Nuyts, K., De Borggraeve, W., Briers, Y., Aertsen, A., Michiels, C.W., Lavigne, R (2015) The zeamine antibiotics affect the integrity of bacterial membranes. Appl Environ Microbiol 81:1139-1146.

[43] McAuliffe, O., Hill, C., Ross, R.P. (1999) Inhibition of Listeria monocytogenes in Cottage cheese manufactured with a lasticin3147producing starter culture J.Appl. Microbiol 8: 251-256.

[44] McAuliffe, O., Ross, R.P., Hill, C. (2001) Lantibiotics: structure, biosynthesis and mode of action. FEMS Microbiol Rev 25: 285308.

[45] McClerren, A.L., Cooper, L.E., Chao Quan Neil. T., Kelleher, N.L., van der Donk, W.A (2006) Discovery and in vitro biosynthesis of haloduracin, a two-component lantibiotic. Proc.Natl.Acad.Sci USA 103: 17242-17248.

[46] Marx, R., Stein, T., Entian, K-D., Glaser, S. J (2001) Structure of the Bacillus subtilis peptide antibiotic subtilosin A determined by 1H-NMR and matrix assisted laser desorption/ionization time-of-flight mass spectrometry. J Protein Chem 20: 501-506.

[47] Mendo, S., Faustino N.A., Sarmento A.C., Amado F., Moir A.J (2004) .Purification and characterization of a new peptide antibiotic produced by a thermotolerant Bacillus licheniformis strain. Biotechnol Lett 26:115-119.

[48] Mikulík, K., Chuan-Ling Qiao., Petřík, T., Puscheva, M., Zavarzin, G.A (1988) Elongation factor Tu of the extreme thermophilic hydrogen oxidizing bacterium Calerobacterium hydrogenophilum Biochem.Biophys. Res.Commun 155: 384-391.

[49] Mikulík, K., Jiránová,A., Manas,J., Spižek, J., Anděra, L., Savelyeva, N.D (1990) Peptide synthesis on ribosimes of an extreme thermophilic hydrogen bacterium Calerobacterium hydrogenophilum. Arch.Microbiol 153:248-253.

[50] Mikulík, K., Anděrová, M (1994) Role of polyamines in the binding of initiator tRNA to the 70S ribosomes of extreme thermophilic bacterium Calerobacterium hydrogenophilum. Arch.Microbiol 161: 508-513.

[51] Mootz, H.D., Finking, R., Marahiel, M.A (2001) 4'-phosphopantetheine transfer in primary and secondary metabolism of Bacillus subtilis. J Biol Chem 276: 37289-37298.

[52] Moyne, A.L., Cleveland, T.E., Tuzun, S (2004) Molecular characterization and analysis of the operon encoding the antifungal lipopeptide bacillomycin D. FEMS Microbiol Lett 234: 43-49.

[53] Muhammad, S.A., Ahmad S., Hameed, A (2009) Report: antibiotic production by thermophilic Bacillus specie SAT-4. Pak J Pharm Sci. 22:339-345.

[54] Mukherjee, A.K. Das, K. (2005) Correlation between diverse cyclic lipopeptides production and regulation of growth and substrate utilization by Bacillus subtilis strains in a particular habitat. FEMS Microbiol Ecol 54: 479-489.

[55] Nakano, M.M., Corbell, N., Besson, J., Zuber, P (1992) Isolation and characterization of sfp: a gene that functions in the production of the lipopeptide biosurfactant, surfactin, in Bacillus subtilis. Mol Gen Genet 232: 313-321.

[56] Nakano, M.M., Zheng, G., and Zuber, P (2000) Dual control of sbo-alb operon expression by the Spo0 and ResDE systems of signal transduction under anaerobic conditions in Bacillus subtilis. J Bacteriol 182: 3274-3277.

[57] Naruse, N., Tenmyo, O., Kobaru, S., Kamei, H., Miyaki, T., Konishi, M., Oki, T (1990) Pumilacidin, a complex of new antiviral antibiotics - production, isolation, chemical properties, structure and biological activity. J Antibiot 43: 267-280.

[58] Novotny, J.F.Jr, Perry, J.J (1992) Characterization of bacteriocins from two strains of Bacillus thermoleovorans, a thermophilic hydrocarbon-utilizing species. Appl Environ Microbiol. 58: 2393-2396.

[59] Oman, T.J,. van der Donk, W.A (2010) Follow the leader: the use of leader peptides to guide natural product biosynthesis. Nat Chem Biol 6: 9-18.

[60] Omura, S., Murata, M., Hanaki, H., Hinotozawa, K., Oiwa, R., Tanaka, H (1984) Phosalacine, a new herbicidal antibiotic containing phosphinothricin. Fermentation, isolation, biological activity and mechanism of action. J Antibiot 37:829-835

[61] Paik, S.H., Chakicherla, A., Hansen, J.N (1998)Identification and characterization of the structural and transporter genes for, and the chemical and biological properties of, sublancin 168, a novel lantibiotic produced by Bacillus subtilis 168. J Biol Chem 273: 2313423142.

[62] Palomo, S., González, I., de la Cruz,M., Martín,J., Tormo,J.R., Anderson,M., . Hill, R.T., Vicente, F., Reyes, F., Genilloud, O (2013) Sponge-Derived Kocuria and Micrococcus spp. as Sources of the New Thiazolyl Peptide Antibiotic Kocurin. Mar Drugs 11: 1071-1086.

[63] Radhakrishnan, M., Balaji, S., Balagurunathan, R (2007) Thermotolerant actinomycetes from Himalayan Mountain-antagonistic potential, characterization and identification of selected strains. Malaysian Appl.Biol 36: 59-65.

[64] Ray, S.S., Johnson, M.C., Ray, B (1989) Bacteriocin plasmids of Pediococcus acidilactis. J. Indian Microbiology 4: 163-171.

[65] Rea, MC., Dobson, A., O'Sullivan, O., Crispie, F., Fouhy, F., Cotter, P.D., Shanahan F., Kiely, B., Hill, C., Ross, R.P (2011) Effect of broad- and narrow-spectrum antimicrobials on Clostridium difficile and microbial diversity in a model of the distal colon. Proc Natl Acad Sci U S A 108: 4639-4644. 
[66] Ren, G., Strobel, J., Sears, M. Park, A (2010) Geobacillus sp., a thermophilic soil bacterium producing volatile antibiotics. Microb.Ecol 60: 130-136.

[67] Ryan, M., Rea, M.C., Hill, C., Ross, R.P (1996). An application of cheddar cheese manufacture for a strain of Lactococcus lactis producing a novel broad spectrum bacteriocin lacticin 3147. Appl. Environ. Microbiol 62, 612-619.

[68] Rince, A (1994) Cloning, expression and nucleotide sequence of the of genes involved in production of lactoccin DR a bacteriocin from Lactococcus lactis susp.lactis Appl Environ. Microbiol 60 1652-1657.

[69] Rollema, H.S., Metzger, J.W., Both, P., Kuipers, O.P., Siezen, R.J (1996) Structure and biological activity of chemically modified nisinA species. Eur.J.Biochem.241, 716-722.

[70] Ross, R.P., Morgan, S., Hill, C. (2002) Preservation and fermentation: past, present and future. Int J Food Microbiol $79: 3-16$.

[71] Scholz, R., Vater, J., Buchharjo, A., Wang, Z., He, Y., Dietel, K., Schwecke, T., Herfort, S., Lasch, P., Borris, R (2014) Amylocyclin a novel circular bacteriocin produced by Bacillus amyloliquefaciens FZB42. J.Bacteriol 196: 1842-1852.

[72] Schneider, T., Sahl, H.G. (2010) Lipid II and other bactoprenol-bound cell wall precursors as drug targets. Curr Opin Investig Drugs $11,157-164$.

[73] Schnell, N., Entian, K.D., Schneider, U., Götz, F., Zahner, H., Kellner, R., Jung, G (1988) Prepeptide sequence of epidermin, a ribosomally synthesized antibiotic with four sulphide-rings. Nature 333: 276-278.

[74] Severina, E., Severin, A., Tomasz, A. J (1998) Antibacterial efficacy of nisin against multidrug-resistant Gram-positive pathogens. Antiot.Chemother 41: 341-347.

[75] Sieber, S.A., Marahiel, M.A (2003) Learning from nature's drug factories: nonribosomal synthesis of macrocyclic peptides. J Bacteriol 185: 7036-7043.

[76] Sylla, J., Alsanius, B. W., Krüger, E., Reineke, A., Strohmeier, S., Wohanka, W (2013) Leaf microbiota of strawberries as affected by bio-logical control agents. Phytopathology 103:1001-1011.

[77] Stein, T., Borchert, S., Kiesau, P., Heinzmann, S., Klöss, S., Klein, C (2002a) Dual control of subtilin biosynthesis and immunity in Bacillus subtilis. Mol Microbiol 44: 403-416.

[78] Stein, T., Borchert, S., Conrad, B., Feesche, J., Hofemeister, B., Hofemeister, J., Entian, K-D (2002b) Two different lantibiotic-like peptides originate from the ericin gene cluster of Bacillus subtilis A1/3. J Bacteriol 184: 1703-1711.

[79] Stein, T., Heinzmann, S., Solovieva, I., Entian, K.D (2003a) Function of Lactococcus lactis nisin immunity genes nisI and nisFEG after coordinated expression in the surrogate host Bacillus subtilis. J Biol Chem 278: 89-94.

[80] Stein, T., Heinzmann, S., Kiesau, P., Himmel, B., Entian, K.D (2003b). The spa-box for transcriptional activation of subtilin biosynthesis and immunity in Bacillus subtilis. Mol Microbiol 47: 1627-1636.

[81] Stein, T., Düsterhus, S., Stroh, A., Entian, K.D (2004) Subtilosin production by two Bacillus subtilis subspecies and variance of the sbo-alb cluster. Appl Environ Microbiol 70: 2349-2353.

[82] Stein, T., Heinzmann, S., Düsterhus, S., Borchert, S., Entian, K.D (2005) Expression and functional analysis of subtilin immunity genes spaIFEG in the subtilin-sensitive host Bacillus subtilis MO1099. J Bacteriol 187: 822-828.

[83] Steinborn, G., Hajirezaei, M.R., Hofemeister, J (2005) Bac genes for recombinant bacilysin and anticapsin production in Bacillus host strains. Arch Microbiol 183: 71-79.

[84] Steller, S., Vollenbroich, D., Leenders, F., Stein, T., Conrad, B., Hofemeister, J (1999) Structural and functional organization of the fengycin synthetase multienzyme system from Bacillus subtilis b213 and A1/3. Chem Biol 6: 31-41.

[85] Steller, S., Sokoll, A., Wilde, C., Bernhard, F., Franke, P., Vater, J (2004) Initiation of surfactin biosynthesis and the role of the SrfDthioesterase protein. Biochemistry 43: 11331-11343.

[86] tenBrink B., Minekus M., van der Vossen J.M., Leer R.J., Huis in't Veld J.H (1994) Antimicrobial activity of lactobacilli: preliminary characterization and optimization of production of acidocin $\mathrm{B}$, a novel bacteriocin produced by Lactobacillus acidophilus M46. J Appl Bacteriol 77:140-148.

[87] Thimon, L., Peypoux, F., Wallach, J., Michel, G (1995) Effect of the lipopeptide antibiotic, iturin A, on morphology and membrane ultrastructure of yeast cells. FEMS Microbiol Lett 128: 101-106.

[88] Thompson, C.J., Seto, H (1995) Bialaphos. Biotechnology 28:197-222.

[89] Tosato, V., Albertini, A,M., Zotti, M., Sonda, S., Bruschi, C.V (1997) Sequence completion, identification and definition of the fengycin operon in Bacillus subtilis 168.Microbiology $143: 3443-3450$.

[90] Tsuge, K., Ohata, Y., Shoda, M (2001a) Gene yerP, involved in surfactin self-resistance in Bacillus subtilis. Antimicrob Agents Chemother 45: 3566-3573.

[91] Tsuge, K., Akiyama, T., Shoda, M (2001b) Cloning, sequencing, and characterization of the iturin A operon J Bacteriol 183: 62656273.

[92] Vater, J., Kablitz, B., Wilde, C., Franke, P., Mehta, N., Cameotra, S.S (2002) Matrix-assisted laser desorption ionization-time of flight mass spectrometry of lipopeptide biosurfactants in whole cells and culture filtrates of Bacillus subtilis C-1 isolated from petroleum sludge. Appl Environ Microbiol 68: 6210-6219.

[93] Vanittanakom, N., Loeffler, W., Koch, U., Jung, G (1986) Fengycin - a novel antifungal lipopeptide antibiotic produced by Bacillus subtilis F-29-3 J Antibiot (Tokyo) 39: 888-901.

[94] Venugopalan V., Tripathi S.K., Nahar, P., Saradhi, P.P., Das, R.H., Gautam, H.K ( 2013) Characterization of canthaxanthin isomers isolated from a new soil Dietzia sp. and their antioxidant activities. J Microbiol Biotechnol 23:237-245.

[95] Walsh, C.T., Fischbach, M.A (2010) Natural products version 2.0: connecting genes to molecules J Am Chem Soc 132:2469-2493. 
[96] Wu L, Wu H, Chen L, Xie S, Zang H, Borriss, R, Gao X (2014) Bacilysin from Bacillus amyloliquefaciens FZB42 has specific bactericidal activity against harmful algal bloom species. Appl Environ Microbiol ;80:7512-20

[97] Xie, L., Miller, L.M ., Chatterjee, C., Averin, O., Kelleher, N.L., van der Donk, W.A (2004) Lacticin 481: in vitro reconstitution of lantibiotic synthetase activity. Science 303:679-681.

[98] Xue, Q.H., Shen, G.H., Wang, D.S (2013) Effects of actinomycetes agent on ginseng growth and rhizosphere soil microflora. Ying Yong Sheng Tai Xue Bao 24: 2287-2293.

[99] Yamanaka K, Reynolds KA, Kersten RD, Ryan KS, Gonzalez DJ, Nizet V, Dorrestein PC, Moore BS (2014) Direct cloning and refactoring of a silent lipopeptide biosynthetic gene cluster yields the antibiotic taromycin A. Proc Natl Acad Sci U S A 111:19571962.

[100] Yazgan, A., Cetin, S., Ozcengiz, G (2003) The effects of insertional mutations in comQ, comP, srfA, spo0H, spo0A and abrB genes on bacilysin biosynthesis in Bacillus subtilis Biochim Biophys Acta 1626: 51-56.

[101] Yu, F., Zaleta-Rivera, K., Zhu,X., Huffman ,J., Millet, J.C., Harris, S.D., Yuen, G., Li, X.C., Du, L '(2007) Structure and Biosynthesis of Heat-Stable Antifungal Factor (HSAF), a Broad-Spectrum Antimycotic with a Novel Mode of Action Antimicrob Agents Chemother 51: 64-72.

[102] Zheng, G., Yan, L.Z., Vederas, J.C., Zuber, P (1999) Genes of the sbo-alb locus of Bacillus subtilis are required for production of the antilisterial bacteriocin subtilosin. J Bacteriol 181: 7346-7355.

[103] Zheng, G., Hehn, R., Zuber, P (2000) Mutational analysis of the sbo-alb locus of Bacillus subtilis: identification of genes required for subtilosin production and immunity. J Bacteriol 182: 3266-3273. 